\author{
辺見秀一
}

国民健康保険福島県泉崎村立病院放射線部

\section{緒 亘}

錯視現象とは，視覚における錯覚のことで，既に色 彩心理学や知覚心理学の分野で数多くの現象が発見さ れている1 6). 医用画像の分野においても，医用画像 の枠の辺縁部の形状の違いが濃度, コントラスト, 粒 状性の見え方に影響を及ほしていることが錯視現象と して知られている7).
錯視現象のなかで医用画像の読影診断(視覚評価)に おいて関連性の深いものとして，「同化および対比の 錯視 8 13)」が考えられる。これには，明るさや色の対 比錯視，図形の大きさの対比錯視などがあり，更に

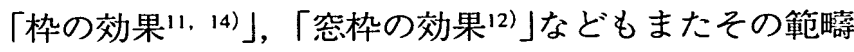
に含まれる。

医用画像の写真濃度についての心理学的相対的な感

\title{
Visual Impression of Photographic Density of the Brain in Head CT Images: Verificaton of Optical Illusion by Visual Subjective Evaluation of Medical Images \\ SHUICH HENMI
}

Department of Radiology. The National Health Insurance Izumizaki Public Hospital. Fukushima Prefecture

Received Dec. 28, 2001; Revision accepted Aug. 6, 2002; Code Nos. 251, 522

Summary

The purpose of this study was to clarify the psychological influence of optical illusion on the photographic density of the brain in head CT images. In this study, I attempted to compare the visual impression of photographic density of the brain using visual subjective evaluation according to observers and cases. The results showed that the visual impression of photographic density of the brain at cerebellar CT depended upon the mode of appearance of the optical illusion (assimilation, contrast, picture frame effect, etc.). In addition, that impression varied according to differences in cases (difference of picture pattern) and observers. Further, it was clarified that the optical illusion had been observed according to individual differences among observers. Moreover, cases could be divided into two main classes. Some cases were recognized as a kind of outline figure(the white skull was recognized as an induction color, and the brain as a non-induction color) with assimilation, and consequently the brain seemed whitish. In other cases (the white skull was not recognized as an induction color) in which there was no assimilation, the brain did not seem whitish. This was considered to have occurred because the degree of influence of the skull on the visual impression of the photographic density of the brain had changed according to differences in cases.

Key words: Assimilation, Contrast, Head computed tomography (CT) image, Photographic density of the brain, Visual impression 
覚值と物理学的絶対的な測定値との関係を撮影部位お よびモダリティごとに解明するためには, 錯視現象に 関する観察者の視覚特性の研究が重要であろう.

以前著者は, 頭部CT (computed tomography) 画像の読 影診断の際,「枠の効果」と呼ばれる錯視現象が生じるた めに, 脳実質写真濃度の見え方(視覚的印象)か浢蓋骨の 色, 背景の色, フレーム枠の色, 被写体の大きさ, 図 柄の違いなどの影響を受けていると報告した ${ }^{14)}$ 。頭部 CT画像が錯視図形としての性質を有している画像の 一つであることが明らかになった報告ともいえよう。

さて, 頭部CT検查は, 脳梗塞, 脳出血, くも膜下 出血, 脳腫瘍など頭蓋内疾患のすべてが適応となり, 病変の局在診断, 質的診断に役立つ有効な検査法であ る.CT所見自体は, 図柄が多種多様にわたるが, 疾 患に必ずしも特異的なものではないことが知られてい る15).

また，頭部CT画像の撮影およびハードコピー像の 作成は抢もに放射線技師(もしくは放射線科医)によっ て行われ，その読影診断は放射線科医のみならず外科 医や内科医など専門分野の異なる多くの医師(観察者) によってなされているのが害状であろう.

そこで今回，観察者個々扔よび症例個々の違いによ つて頭部CT画像の脳実質写真濃度の見え方に变化が 生じるのか, それは同化, 対比, 枠の効果といった観 察者の錯視現象の現れ方が異なるためなのか, 更に頭 蓋骨が脳実質写真濃度の見え万に及ほす影響の度合い は症例の違いに依存しているのかを解明するために， パーソナルコンピュータ(以下, パソコン) と画像処理 ソフトで作成した画像を視覚的主観評価によって比較 検討し, 錯視現象の現れ方と写真濃度の視覚的印象の 関連性について考察した.

本報告の目的は, 脳梗塞や脳出血などの症例を含ん だ頭部CT画像における脳実質写真濃度の見え方を専 門分野の異なる観察者による視覚的主観評価で検討 し, 錯視現象が写真濃度に与える影響を知覚心理学的 に解明することにある。

\section{1. 方 法}

\section{1-1 使用機材}

パソコン : Macintosh Performa 5210

(アップルコンピュータ株式会社製)

スキャナ：GT-8500ART

(セイコーエプソン株式会社製)

プリンタ : MJ-800C

（セイコーエプソン株式会社製）

アプリケーションソフト：Photoshop LE-J

（アドビシステムズ株式会社製）

CTスキャナ：TCT-300
（東芝メディカル株式会社製）

マルチカメラ：CTI-05A

（東芝メディカル株式会社製）

\section{1-2 サンプル画像の作成}

(1)小脳レベルの頭部CT画像 (OMラインより頭頂部へ 約40〜 $50 \mathrm{~mm}$ 上の $10 \mathrm{~mm}$ 厚のスライス像)をスキャナを 介してパソコンに入力した. サンプル画像に用いた症 例の内訳は, 脳梗塞 [3], 出血性梗塞 [1], 脳出血 [2]，〈も膜下出血[3]の計 9 例であり, すべて適正な 表示条件 (ウインド值, ウインド幅)で表示されている ものである.

前報14)では，フレーム枠として白枠と黒枠の 2 種類 に大別したが, マルチカメラからレーザーイメージャ への移行が進むなか, 白枠の画像を目にする機会が減 少していることを考慮し，フレーム枠に関して白枠と 黒枠の二つに分類することは割愛した.

(2) 頭蓋骨および背景を一つの枠と考え，オリジナル の画像 $[\mathrm{A}]$ に対して三つの画像 $[\mathrm{B}],[\mathrm{C}],[\mathrm{D}]$ を画像 処理ソフトを使用してパソコン上で作成し，おのおの 1 枚ずつB5用紙に $120 \%$ に拡大して横に印刷した。四 つの画像の分類は前報14) と同様, [A]はオリジナルの 画像で背景が黒, 頭蓋骨が白, [B]は背景が黒で, 頭 蓋骨も黒, [C]は背景が白で, 頭蓋骨も白, [D]は背 景が白で，頭蓋骨が黒とした。

印刷の際，画像全体を死色の用紙の上に置いて比較 観察している状況を想定し画像全体を灰色の枠で取り 囲んだが，これは用紙の白色の影響を減らす目的も兼 ねている.

このように $[\mathrm{A}]$ というオリジナルの画像に対して相 対する画像を 3 種類ずつ作成した，なお，いずれの画 像も脳実質写真濃度は同一である. 更に, 画像処理の 関係上，頭皮と白枠の一部分がわずかに輪郭となって 描出されているものもあるが，これはそのまま残し た。しかし, グレースケール, 検査日時, 文字データ などはすべて消去することにした。

また, スキャナ, パソコン, アプリケーションソフ ト，プリンタの 4 者を脳実質写真濃度およびコントラ ストがより忠実に印刷されるように設定したため, 結 果としてCT画像の背景の濃度が多少薄めになってい る.

\section{1-3 視覚的主観評価 \\ 1-3-1 視覚的主観評価 1}

医師 3 名(外科医 [Dr.Su】：1, 小巟科医【Dr.Pe】：1, 心臟血管外科医【Dr.He】：1)，放射線技師(Rt.Co】 1 名 の計 4 名で, 先ほど作成した画像 $[\mathrm{A}],[\mathrm{B}],[\mathrm{C}]$, [D] から 2 個ずつ任意に選択した画像を九つの各症例 
ごとに脳実質写真濃度の見え方について比較観察 した16〜20). その数は 1 症例あたり ${ }_{4} \mathrm{C}_{2}$ 通り(6 通り) であり，観察者 1 名あたり比較するのは ${ }_{4} \mathrm{C}_{2}$ (通 り) $\times 9$ (症例 $)=54$ (通り)である。

観察時間および観察距離は任意とし，二つのサ ンプル画像に対して特別にライトは照射しなかっ た（実際にはどの観察者も観察距離は40～50cm程 度であった)。

なお, 評価は午前 11 時から午後 2 時にかけて行 い, 1 回に 2 症例までとし次の評価は画像に眼が 慣れてしまうのを避けるために，そして四つの画 像の分類の意味が把握されないがために 1 週間以 上間隔を空けた。

評点の与え方は，二つのサンプル $[\mathrm{A}]$ と $[\mathrm{B}]$ を 比較したとき，「[A]が明らかに[B]よりも白っぽ く感じられる」+2 点, 「[A]が[B]よりもやや白っ ぽく感じられる」+1 点, 「[A]と $[\mathrm{B}]$ はほほ同じ」 0 点, 「[A]が[B]よりもやや黒っぽく感じられる」-1 点, 「[A]が明らかに[B]よりも黒っぽく感じられる」ー 2 点の 5 段階評定法を採用した。

このように 2 枚の画像を一つのペアにして評点を与 え, それぞれの観察者の評点結果の合計と標準偏差を 導いた（上記の場合， [A] [B]の評点が得られるが， [B] [A]とした場合， [A][B]の評点の符号が反対にな る).

更に，その結果に対して危険率 5\%で一標本符号検 定法を行った。

次に一元配置分散分析法とシェッフェの方法による 多重比較検定法を用いて，6通りの組み合わせごとに 観察者個々の見え方の違い，および[A]に対する [B]，[C]，[D]の見え方の違いすなわち，[A][B]， $[\mathrm{A}][\mathrm{C}],[\mathrm{A}][\mathrm{D}]$ の 3 群間の見え方の違いを 4 人の観 察者ごとに統計学的検討を加えた.

\section{1-3-2 視覚的主観評価 2}

医師 7 名(外科医【Dr.Su 1-4】：4，小巟科医(Dr.Pe】：1, 心臓血管外科医 (Dr.He】：1, 形成外科医[Dr.Pl]：1)，放 射線技師【Rt.Co】1 名の計 8 名で脳梗塞[2], 脳出血. [1], くも膜下出血[1]の四つの症例をそれぞれ四つの 画像 $[\mathrm{A}],[\mathrm{B}]$, [C]，［D]から 2 個ずつ任意に選択し て 5 段階のスコアで脳実質写真濃度の見え方を評価し た. 実験方法および評点の与え方は視覚的主観評価 1 と同じである。

次に一元配置分散分析法およびシェッフェの方法に よる多重比較検定法を用いて，視覚的主観評体 1 と同 様に $[\mathrm{A}][\mathrm{B}] ，[\mathrm{~A}][\mathrm{C}] ，[\mathrm{~A}][\mathrm{D}]$ の 3 群間の見え方の 違いを四つの症例ごとに統計学的検討を加えた。

Table 1に視覚的主観評価 1，2 で使用したサンプル 画像に用いた症例の疾患名および観察者の人数を示
Table 1 Names of the diseases of sample images used for visual subjective evaluation in this study, and the number of observers.

\begin{tabular}{clcc}
\hline \hline \multirow{2}{*}{ Case } & Disease & \multicolumn{2}{c}{$\begin{array}{c}\text { Visual subjective } \\
\text { evaluation }\end{array}$} \\
\cline { 3 - 4 } & & No.1 & No.2 \\
\hline 1 & $\begin{array}{l}\text { Subarachnoidal } \\
\text { hemorrhage/serious case }\end{array}$ & 0 & 0 \\
2 & Subarachnoidal hemorrhage & 0 & 0 \\
3 & Cerebral infarction/serious case & 0 & $\bigcirc$ \\
4 & Cerebral infarction/mild case & 0 & 0 \\
5 & Cerebral infarction/mild case & 0 & \\
6 & Cerebral hemorrhage/serious case & 0 & \\
7 & Cerebral hemorrhage/serious case & 0 & 0 \\
8 & Hemorrhagic infarction/serious case & 0 & \\
9 & Subarachnoidal hemorrhage & 0 & \\
& The number of observers & 4 & 8 \\
\hline
\end{tabular}

す.二重丸印(○)がそれぞれの評価に使用したサンプ ル画像である。

\section{2. 結 果}

\section{2-1 視覚的主観評価1}

4 名の観察者によって九つの症例を比較観察して得 られた評点の合計と一標本符号検定法による $\mathrm{p}$ 值を Table 2に示す.

統計学的に有意差の認められた組み合わせは，放射 線技師（以下，【Rt.Co】)の[A] [C]，[A] [D]，[B] $[\mathrm{C}],[\mathrm{B}][\mathrm{D}]$, 外科医 (以下, 【Dr.Su】)の[A] [C], $[\mathrm{A}][\mathrm{D}],[\mathrm{B}][\mathrm{C}],[\mathrm{B}][\mathrm{D}]$ ，小览科医（以下， 【Dr.Pe】)の[A][D], [B] [C], [B][D]，心臓血管外科 医（以下，【Dr.He】)の $0 \mathrm{~A}][\mathrm{B}],[\mathrm{A}][\mathrm{C}],[\mathrm{A}][\mathrm{D}]$, $[\mathrm{B}][\mathrm{C}],[\mathrm{C}][\mathrm{D}]$ であった.なお,【Dr.Pe】の $[\mathrm{A}][\mathrm{C}]$ に関しても同様にばらつきの少ない傾向が認められ た。

6 通りの組み合わせごとに 4 人の観察者個人個人の 見え方を一元配置分散分析法によって検定した結果， 有意差の認められた組み合わせは次のとおり.

[A] [B] では，【Rt.Co】と【Dr.Su】間，【Rt.Co】と 【Dr.He】間, [A] [C]では,【Rt.Co】と【Dr.He】間, 【Dr.Su】と【Dr.He】間，【Dr.Pe】と【Dr.He】間， [B][C] では,【Rt.Co】と【Dr.Su】間，【Rt.Co】と【Dr.He】間， 【Dr.Su】と【Dr.He】間，【Dr.Pe】と【Dr.He】間， [B] [D] では,【Rt.Co】と【Dr.He】間，【Dr.Su】と【Dr.He】間， 【Dr.Pe】と【Dr.He】間，[C] [D]では,【Rt.Co】と 【Dr.He】間であった。

次に $[\mathrm{A}][\mathrm{B}],[\mathrm{A}][\mathrm{C}],[\mathrm{A}][\mathrm{D}]$ の 3 群間の評点の 平均值および標準偏差をFig.1 (a)に示す.このグラフ は，グラフ上(+)側では[A]より他方が白っぽく，グ 
ラフ上(-)側では $[\mathrm{A}] よ り$ 他方が黒っぽく見えて いることを意味する.同様に $[\mathrm{B}][\mathrm{A}] ，[\mathrm{~B}][\mathrm{C}]$,

[B] [D]の 3 群間の評点の平均値および標準偏差 をFig.1(b)に示す。

また，[A]に対する $[\mathrm{B}] ，[\mathrm{C}] ，[\mathrm{D}]$ の見え方の 違い, すなわち $[\mathrm{A}][\mathrm{B}],[\mathrm{A}][\mathrm{C}],[\mathrm{A}][\mathrm{D}]$ の 3 群 間についての観察者個々の比較で一元配置分散分 析法の結果, 有意差の認められた組み合わせは, 【Rt.Co】の $[\mathrm{A}][\mathrm{B}]$ と $[\mathrm{A}][\mathrm{C}]$ 間, $[\mathrm{A}][\mathrm{B}]$ と $[\mathrm{A}][\mathrm{D}]$ 間,【Dr.He】の $[\mathrm{A}][\mathrm{B}]$ と $[\mathrm{A}][\mathrm{C}]$ 間, $[\mathrm{A}][\mathrm{B}]$ と [A][D]間であった.

\section{2-2 視覚的主観評価 2}

8 名の観察者によって四つの症例を比較観察し て得られた評点の合計と一標本符号検定法によるp值 をTable $3 に ， 6$ 通りの組み合わせのなかで $[\mathrm{A}][\mathrm{B}]$ お よび $[\mathrm{B}][\mathrm{C}] に$ 関する観察者個々の評点とその合計な らびに一標本符号検定法によるp值をそれぞれTable 4, Table 5に示す.

統計学的に有意差の認められた組み合わせは，くも 膜下出血 (症例 1) の[A] [D], 脳出血 (症例 7) の [A] [D], 脳梗塞 1 (症例 $3 /$ 重症) $[\mathrm{C}][\mathrm{D}]$, 脳梗塞 2 (症 例 4/軽症)の [A] [D]であった.なお，くも膜下出血 （症例 1)の $[\mathrm{A}][\mathrm{B}]$, [B] [D]拈よび脳梗塞 2(症例 4／ 軽症)の[A] [B]についてもばらつきの少ない傾向があ った.

次に, $[\mathrm{A}][\mathrm{B}],[\mathrm{A}][\mathrm{C}],[\mathrm{A}][\mathrm{D}]$ の 3 群間につい て症例ごとに評点の平均值および標準偏差をFig. 2に 示す.

[A] [B], [A] [C], [A] [D]の 3 群間について四つ の症例ごとに一元配置分散分析法を行った結果, くも 膜下出血 (症例 1) において $[\mathrm{A}][\mathbf{B}]$ と $[\mathrm{A}][\mathrm{C}]$ 間， [A] $[\mathrm{C}]$ と $[\mathrm{A}][\mathrm{D}]$ 間の二つの組み合わせで有意差が認めら れた。また，脳梗塞 2 (症例 $4 /$ 軽症)において $[\mathrm{A}][\mathrm{C}]$ と $[\mathrm{A}][\mathrm{D}]$ 間で有意差は認められていないが，見え方 に違いの傾向があった。

\section{3. 考 察}

\section{3-1 観察者の違い}

まず着目すべき点として，有意差の認められた $[\mathrm{A}]$ $[\mathrm{C}]$ と $[\mathrm{B}][\mathrm{C}]$ 二つで観察者の 1 名の符号が逆になっ ていることである(Table 2, Fig. 1)。これは, [A] [C] と $[\mathrm{B}][\mathrm{C}]$ の場合, 観察者の 1 名は他の 3 名とは別の 方を白っぽいと感じていることを意味する.

次に着目すべき点として，[A][D]の見えすでは 4 名の観察者全員が符号がプラス $(+)$ ，すなわち「[A]が [D]よりも白っぽい」に有意差が認められていることが 挙げられる。これは，一元配置分散分析法の結果でも
Table 2 Total score obtained by visual subjective evaluation No. 1 and probability values ( $p$-value) obtained by one sample sign test from the results of the evaluation. Numerical value in parentheses shows total score.

\begin{tabular}{cllll}
\hline \hline & \multicolumn{4}{c}{ Observer } \\
\cline { 2 - 5 } & \multicolumn{1}{c}{ Rt.Co } & \multicolumn{1}{c}{ Dr.Su } & \multicolumn{1}{c}{ Dr.Pe } & \multicolumn{1}{c}{ Dr.He } \\
\hline AB & $0.1797(-5)$ & $0.1797(5)$ & $0.375(3)$ & $0.0039(9)$ \\
AC & $0.0156(9)$ & $0.0391(7)$ & $0.0625(6)$ & $0.0039(-9)$ \\
AD & $0.0039(13)$ & $0.0039(9)$ & $0.0156(8)$ & $0.0391(7)$ \\
BC & $0.0039(16)$ & $0.0039(9)$ & $0.0039(13)$ & $0.0078(-8)$ \\
BD & $0.0391(7)$ & $0.0039(9)$ & $0.0156(9)$ & $0.375(-3)$ \\
CD & $0.375(-3)$ & $0.1797(5)$ & $>.9999(1)$ & $0.0039(9)$ \\
\hline
\end{tabular}

Probability values (Total scores)

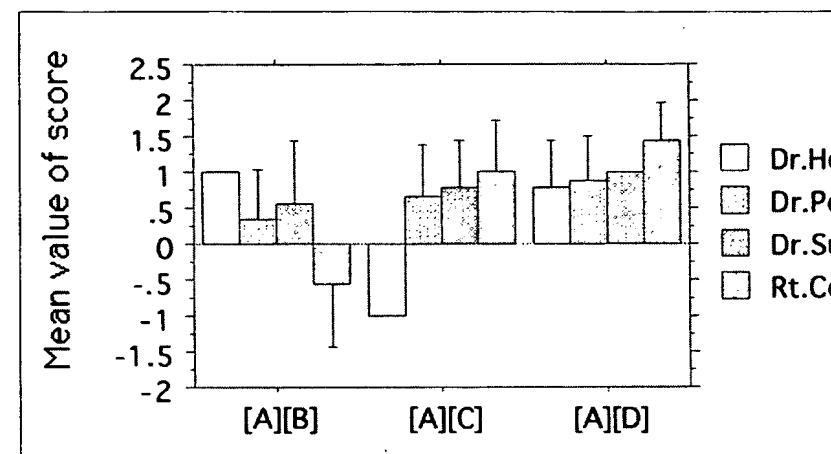

Combination of the comparison image

(a)

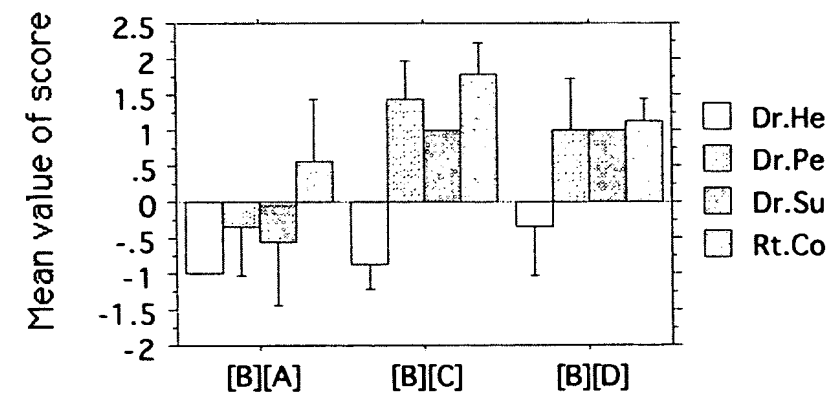

Combination of the comparison image

(b)

Fig. 1 Means and standard deviation(SD) of the scores obtained by visual subjective evaluation No. 1 .

Dr. He: Heart surgeon

Dr. Pe: Pediatrician

Dr. Su: Surgeon

Rt. Co: Radiological technologist

(a): Comparison between three categories ( $[A][B]$, [A] [C] and [A] [D] ).

(b): Comparison between three categories ( $[\mathrm{B}][\mathrm{A}]$, [B] [C] and [B] [D] )

[A] [D]の見え方に有意差は認められていないことか らも明らかである(なお， [A] [D]以外の見え方では， 観察者間に有意差が認められている)．症例の違いに よらず，観察者の違いによらず一定の見え方がなされ 
Table 3 Total score obtained by visual subjective evaluation No. 2 and probability values ( $p$-value) obtained by the one-sample sign test from the results of evaluation. Numerical value in parentheses shows total score.

\begin{tabular}{ccccc}
\hline \hline & \multicolumn{4}{c}{ Case } \\
\cline { 2 - 5 } & $\begin{array}{l}\text { Subarach- } \\
\text { noidal } \\
\text { hemorrhage } \\
\text { [case1] }\end{array}$ & $\begin{array}{l}\text { Cerebral } \\
\text { hemorrhage }\end{array}$ & $\begin{array}{l}\text { Cerebral } \\
\text { infarction 1 }\end{array}$ & $\begin{array}{l}\text { Cerebral } \\
\text { infarction 2 }\end{array}$ \\
[case7] & [case3] & [case4] \\
\hline AB & $0.0703(6)$ & $0.7266(2)$ & $>.9999(0)$ & $0.0703(6)$ \\
AC & $0.4531(-1)$ & $0.4531(4)$ & $0.6875(2)$ & $>.9999(1)$ \\
AD & $0.0078(8)$ & $0.0078(8)$ & $0.2891(5)$ & $0.0156(8)$ \\
BC & $0.7266(4)$ & $0.2891(6)$ & $0.7266(3)$ & $>.9999(1)$ \\
BD & $0.0625(5)$ & $0.1250(7)$ & $0.375(3)$ & $0.2188(5)$ \\
CD & $>.9999(0)$ & $0.7266(2)$ & $0.0156(7)$ & $0.1250(5)$ \\
\hline
\end{tabular}

Probability values (Total scores)

Table 4 Individual score and total score of each observer between [A] and $[B]$ by visual subjective evaluation No. 2, and probability values ( $p$-value) obtained by the one-sample sign test.

\begin{tabular}{|c|c|c|c|c|c|c|c|c|c|c|}
\hline \multirow[t]{2}{*}{$A B$} & \multicolumn{10}{|c|}{ Observer } \\
\hline & Rt.Co & Dr.Pe & Dr.Su1 & Dr.Su2 & Dr.Su3 & Dr.Su4 & Dr.He & Dr.PI & $P$ & $\mathrm{~T}$ \\
\hline $\begin{array}{l}\text { Subarach- } \\
\text { noidal } \\
\text { hemorrhage } \\
\text { [case1] }\end{array}$ & 1 & 1 & 1 & 1 & -1 & 1 & 1 & 1 & 0.0703 & 6 \\
\hline $\begin{array}{l}\text { Cerebral } \\
\text { hemorrhage } \\
\text { [case7] }\end{array}$ & -1 & 1 & 1 & -1 & 1 & -1 & 1 & 1 & 0.7266 & 2 \\
\hline $\begin{array}{l}\text { Cerebral } \\
\text { infarction } 1 \\
\text { [case3] }\end{array}$ & -1 & 1 & -1 & -1 & 1 & -1 & 1 & 1 & $>.9999$ & 0 \\
\hline $\begin{array}{l}\text { Cerebral } \\
\text { infarction } 2 \\
\text { [case4] }\end{array}$ & -1 & 1 & 1 & 1 & 1 & 1 & 1 & 1 & 0.0703 & 6 \\
\hline
\end{tabular}

Table 5 Individual score and total score of each observer between $[B]$ and $[C]$ by visual subjective evaluation No. 2, and probability values ( $p$-value) obtained by the one-sample sign test.

\begin{tabular}{|c|c|c|c|c|c|c|c|c|c|c|}
\hline \multirow[t]{2}{*}{$B C$} & \multicolumn{10}{|c|}{ Observer } \\
\hline & Rt.Co & Dr.Pe & Dr.Su1 & Dr.Su2 & Dr.Su3 & Dr.Su4 & Dr.He & Dr.PI & $P$ & $\mathrm{~T}$ \\
\hline $\begin{array}{l}\text { Subarach- } \\
\text { noidal } \\
\text { hemorrhage } \\
\text { [case1] }\end{array}$ & 2 & 2 & 1 & -1 & 1 & 1 & -1 & -1 & 0.7266 & 4 \\
\hline $\begin{array}{l}\text { Cerebral } \\
\text { hemorrhage } \\
\text { [case7] }\end{array}$ & 2 & 2 & 1 & 1 & 1 & 1 & -1 & -1 & 0.2891 & 6 \\
\hline $\begin{array}{l}\text { Cerebral } \\
\text { infarction } 1 \\
\text { [case3] }\end{array}$ & 2 & 1 & 1 & 1 & 1 & -1 & -1 & -1 & 0.7266 & 3 \\
\hline $\begin{array}{l}\text { Cerebral } \\
\text { infarction } 2 \\
\text { [case4] }\end{array}$ & 2 & 2 & 1 & 0 & -1 & -1 & -1 & -1 & $>.9999$ & 1 \\
\hline
\end{tabular}

P: probability values $\quad T$ : total scores 
ていることを意味する。

視覚的主観評価 1 において一標本符号検定法で有意 差の認められた組み合わせは， $[\mathrm{A}][\mathrm{C}],[\mathrm{B}][\mathrm{C}]$ の見 え方のように，観察者の違いによって見え方が反対に なる場合と，[A] [D]の見え方のように，症例の違い によらず，観察者の違いによらず一定の見え方がなさ れる場合があることが検証できた．更に，[A][B]， $[\mathrm{B}][\mathrm{D}] ，[\mathrm{C}][\mathrm{D}]$ の見え方のように，特定の観察者の みにおいて症例の違いによらず一定の見え方がなされ るため，有意差の認められた場合と症例の違いによっ て観察者個人個人の見え方が変化するため有意差の認 められない場合とがあることも検証できた，

また，観察者の違いによって有意差の生じた組み合 わせが異なっていることが，一元配置分散分析法の結 果でも明らかである。

Fig. 3は, 脳出血の症例 (症例 7) で[B]と [C]を比較 しているものである。

この [B] [C]の場合, 観察者の 3 名は符号がプラス (+)であるので,「[B]が[C]よりも白っぽい」と評価し ている.

一般に明るさの対比は周囲が明るいために暗い部分 がますます暗く感じられるのが原因である(周囲が暗 いと明るい部分がますます明るく感じられるのが原因 ではない)ことが知られている5゙が，観察者の 3 名は [C]の画像で背景の幅を太いと認識するので枠の効果 が成立し，背景の色と対比になると判断しているた め, [C]の画像が黒っぼく見え, 結果として「[B]が [C]よりも白っぽく見える」と考えられる.

それに対し，観察者の 1 名は符号がマイナス (-)で あるので，「[B]が[C]よりも黒っぽい」と評価してい ることになる。これは, [C]の画像で脳実質が背景の 色と対比になるとは判断されず，むしろ [B]と $[\mathrm{C}] の$ 両方の画像で背景の色と同化になると判断しているた めではないかと考えられる. 特に [C]の脳実質の辺縁 がシャープでなく，脳出血による影響でややボケてい ることも同化を引き起こさせる要因となっているのか もしれない.ただし，この症例に限らず別の症例でも 観察者の 1名は，同様の見え方を呈しているので，脳 実質の辺縁部の形状の相違で説明がつかない場合も存 在する.

視覚的主観評価 1 の[B][C]の見え方では，符号が マイナス (-)，すなわち背景の色と同化になると判断 している観察者は，心臓血管外科医【Dr.He】であった が，一元配置分散分析法の結果でも，この観察者と他 の 3 人の観察者間の $[\mathrm{B}][\mathrm{C}]$ の見え方に有意差が認め られている。，一方，視覚的主観評価 2 の [B] [C]の見 え方では，この心臓血管外科医(Dr.He】の他に, 形成 外科医【Dr.Pl】も同様に，符号がマイナス(-)，すなわ

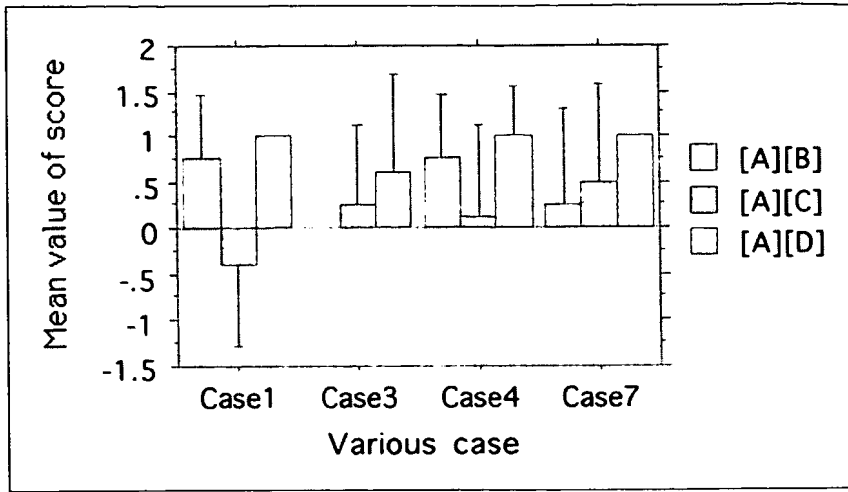

Fig. 2 Means and standard deviation(SD) of the scores obtained by visual subjective evaluation No. 2 . Case 1: Subarachnoid hemorrhage

Case 3: Cerebral infarction (serious case)

Case 4: Cerebral infarction (mild case)

Case 7: Cerebral hemorrhage (serious case)

ち背景の色と同化になると判断している(Table 5).

では，なぜ $[\mathrm{B}] と[\mathrm{C}]$ を比較すると，背景の色と対 比とみる観察者と同化とみる観察者とが存在するので あろうか．同一の頭部CT画像の脳実質写真濃度の見 え方において，同化になるのか，対比になるのか，枠 の効果が成立するのかといった錯視現象の現れ方に個 人差が生じるのはなぜであろうか.

さて，注意深く画像を凝視してみると，その見え方 に色彩的特性と照明的特性との二つの特徽が現象的に 起きることが視覚的印象における二重性の問題として 知られている．この場合，前者としての見え方では同 化的現象を, 後者としての観察視点では対比的効果を 知覚するようになる13).

また，画像を観察する際，まず全体的に見るのか， あるいは部分的に拘りながら見るのか，でも見え方が 異なってくることも知られている。この場合, 前者で あれば図として体制化され同化になり，後者であれば 対比になるのである12,13).

このように同一の画像を観察しても，観察者には同 化と対比の両方の見え方が起こり得るのである。これ は，頭部CT画像の脳実質写真濃度の見え方にも当て

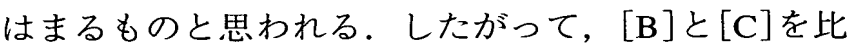
較すると背景の色と同化とみる観察者と対比とみる観 察者の両者が存在する理由として，

(i)色彩的特性と照明的特性の両者の見え方 (視覚的 印象)が起こること，

(ii) 画像を認識する際の観察の仕方 (全体的に見るの か，部分的に拘りながら見るのかにに個人個人で 違いがあること，

(iii) 同化と対比とが入れ換わるポイントが個人個人で

異なること， などが考えられる。 


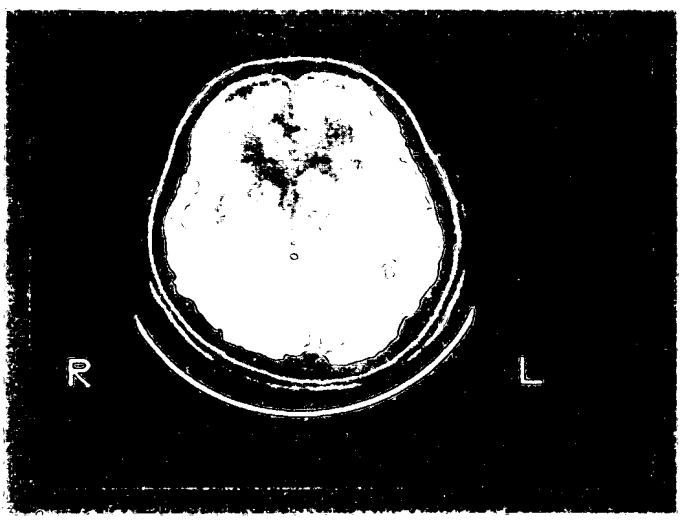

[B]

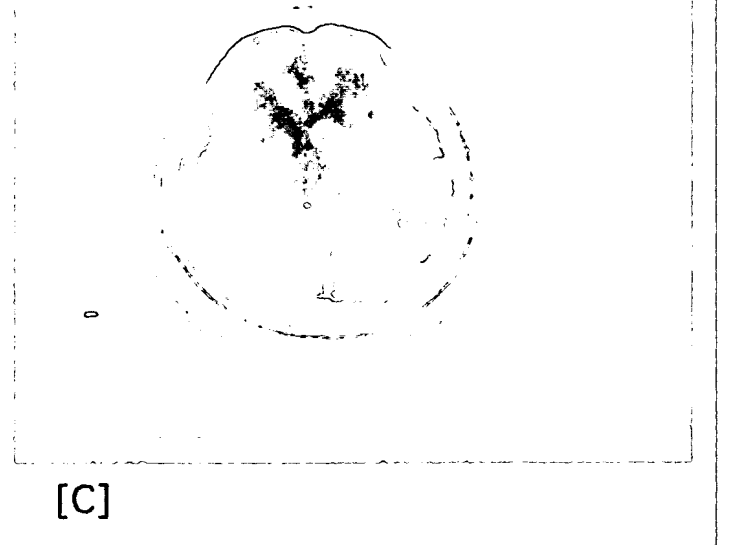

Fig. 3 Comparison between [B] and [C] for cerebellar CT images: case No. 7, cerebral hemorrhage (serious case).

\section{3-2 症例の違い}

視覚的主観評価 2 において一標本符号検定法の結 果, 着目すべき点として，[A][D]の見え方で脳梗塞 1 (症例 $3 /$ 重症) 以外の三つの症例で「[A]が[D]よりも 白っぼく見える」に，[C][D]の見え方では，その脳梗 塞 1 (症例 $3 /$ 重症) で「[C]が[D]よりも白っぽく見え る」に有意差が認められたこと，更に[A][B]の見え方 では, くも膜下出血 (症例 1) と脳梗塞 2 (症例 4／軽症) の症例で「[A]が[B]よりも白っぽく見える」に，[B] [D]の見え方では，〈も膜下出血(症例 1)で「[B]が [D]よりも白っぽく見える」に有意差は認められていな いが，ばらつきの少ない傾问が認められたことが挙げ られる。

これは，観察者によってはある症例で他の観察者と 異なる見え方を呈している場合もある(その場合，有 意差は認められにくくなる)ので，一概には断言でき ないが，少なくとも有意差の認められたものについて は，観察者の違いによらず症例の違いによって脳実質 写真濃度の見え方に差が生じているといえる。

また，㕕範囲に及んでいる脳梗塞 1 (症例 $3 /$ 重症) と小領域に限局している脳梗塞 2 (症例 4／軽症) とで は，有意差の生じた組み合わせが異なっている(Table 3). 梗塞が起こっている領域 (X線低吸収域)が, どの 程度なのか一広範囲に及んでいるのか，小領域に限局 しているのか, CT画像上の図柄の違いによって同じ 脳梗塞でも脳実質写真濃度の見え方が変わっていると いえる。

一元配置分散分析法の結果，〈も膜下出血(症例 1) では，[A]に対する[B]と [C]の見え方および[A]に対 する $[\mathrm{C}]$ と [D]の見え方に有意差が認められ，脳梗塞 2 (症例 4/軽症)では，[A]に対する [C]と [D]の見え方 に違いの傾向が認められている。
このことから，症例によっては，[A]に対する [B] と $[\mathrm{C}]$ の見え方および $[\mathrm{A}] に$ 対する $[\mathrm{C}]$ と [D]の見え方 に有意差が認められる場合と, 有意差が認められない 場合とがあることが明らかになった，オリジナルの画 像 [A]と比較した場合, 症例の違いによって脳実質写 真濃度の見え方が变化することが分散分析法でも検証 できたといえよう。したがって，脳実質写真濃度の見 え方が症例の違いで変わるので, どの症例でも常に同 一表示条件 (ウインド值, ウインド幅)でハードコピー 像を作成するのではなく，脳奏質写真濃度の視覚的印 象の立場から症例ごとに表示条件(特にウインド值の 上げ下げ)を変えるべきと思われる．今後の検討課題 としたい.

さて, 視覚的主観評価 1 では 4 名の観察者個々の 見え方は症例の違いに左右されるのか, 視覚的主観評 価 2 では四つの症例個々の見え方は観察者の違いに左 右されるのかを前者は九つの症例のデータを, 後者は 8 名の観察者のデータをおのおの検証したことにな る. 症例のデータ, あるいは観察者のデータに特化し たデータが含まれている可能性があるので, より正確 なデー夕を得るために各専門分野ごとの観察者の人 数, 症例の種類および数を増やしたうえで, 多元配置 分散分析や多変量解析などの統計学的検定が必要であ ろう。

\section{3-3 頭蓋骨の影響}

頭部CT画像は，色彩心理学的には被誘導色である 脳実質が誘導色である白い頭蓋骨，もしくは黒い背景 に囲まれた輪部図形の一種とみなすこともできよう. ここでいう輪郭図形とは, 誘導色で被誘導色の周囲を 囲んだ形態を指す。この場合，誘導色の輪郭線が細い ときは同化になり，太くなれば対比へと移行すること 


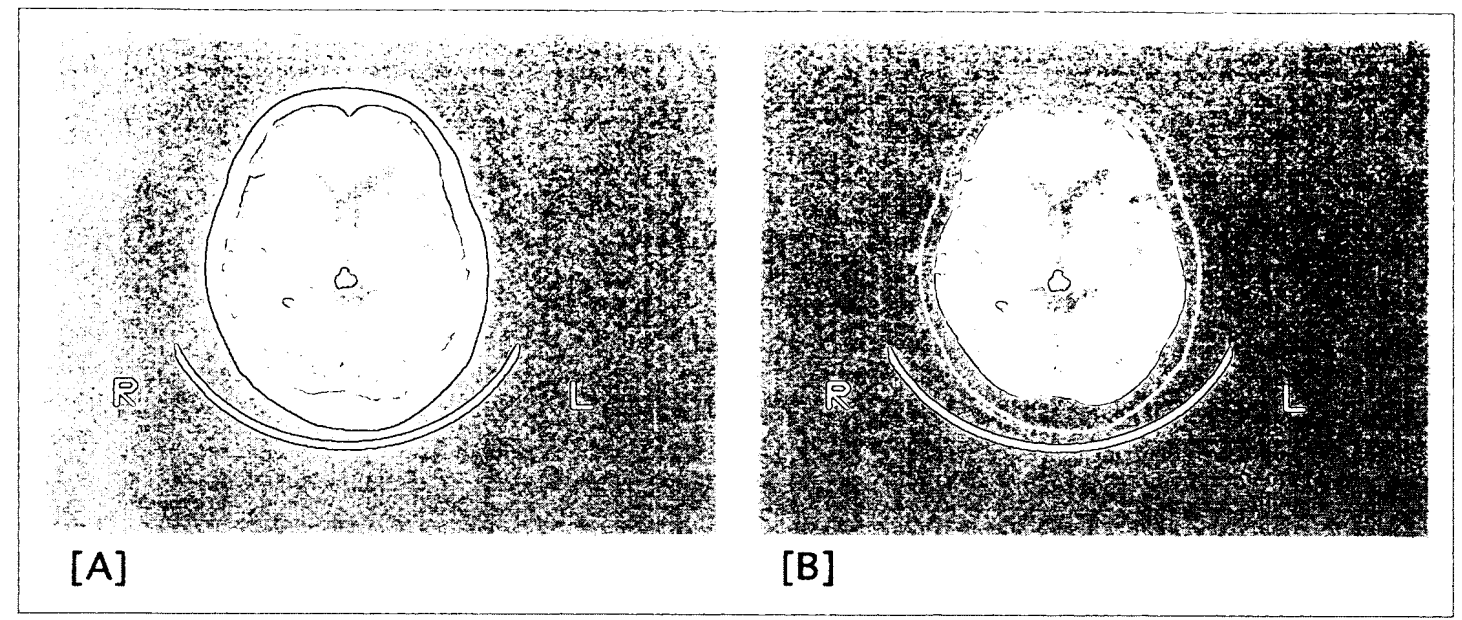

Fig. 4 Comparison between $[\mathrm{A}]$ and $[\mathrm{B}]$ for cerebellar $\mathrm{CT}$ images: case No. 4, cerebral infarction; No. 2 (mild case).

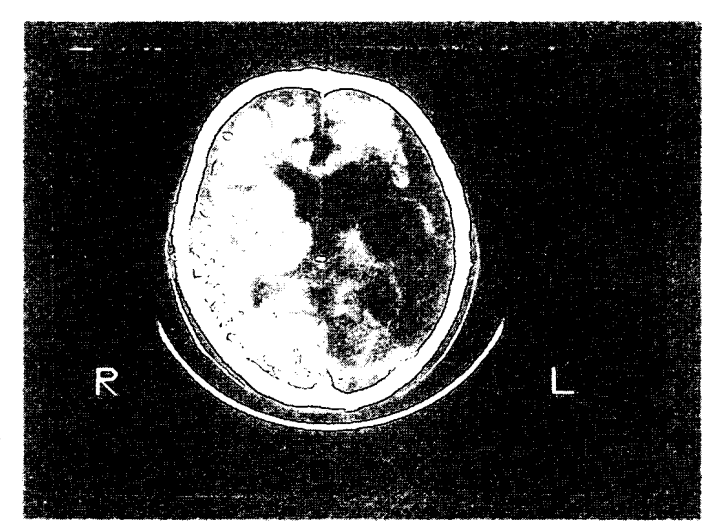

[A]

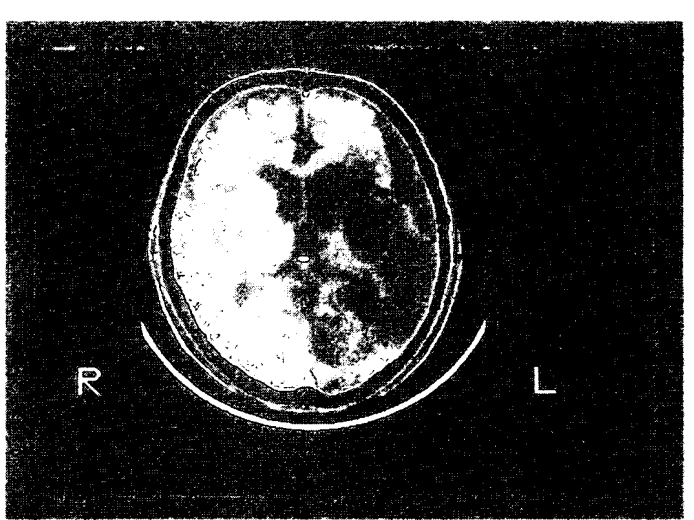

[B]

Fig. 5 Comparison between $[A]$ and $[B]$ for cerebellar $C T$ images: case No. 3, cerebral infarction; No. 1 (serious case).

が知られているが，同化と対比における両色の面積比 率の限界については明らかにされていない13).

視覚的主観評価 1 の結果, [A] [B]の見え方は, $\Gamma[\mathrm{A}]$ が $[\mathrm{B}]$ より白っぽく見える」に有意差の生じた観 察者は 4 名中 1 名だった (Table 2)ことから，[A]と [B]を比較したとき, 脳実質写真濃度の見え方は症例 の違いの影響を受けているといえる。

更に，一元配置分散分析法の結果，[A][B]の見え 方は放射線技師【Rt.Co】と外科医【Dr.Su】および放射線 技師【Rt.Co】と心臟血管外科医【Dr.He】の 2 群間で有意 差が認められている。これは，[A][B]の見え方は症 例ごとに，観察者ごとに異なる場合があることを意味 する。

Fig. 4は, 脳梗塞 2 (症例 4/軽症) の $[\mathrm{A}]$ と [B]を比 較したものである．視覚的主観評価 2 の結果，「[A] の方が[B]よりも白っぽく見える」に有意差は認められ ていないものの, ばらつきの少ない傾向があった症例
である.一方, Fig. 5は, 脳梗塞 1 (症例 $3 /$ 重症)の $[\mathrm{A}]$ と $[\mathrm{B}]$ を比較したもので, 視覚的主観評価 2 の結 果, 有意差は認められなかった症例である.

8 名の観察者による視覚的主観評価 2 で, 観察者個 々の評点を検討してみると, くも膜下出血 (症例 1) と 脳梗塞 2 (症例 4/軽症) は, それぞれ 1 名の観察者を 除いて残り7名すべてが「[A]が[B]よりも白っぽく見 える」と評価している。これは, 白い頭蓋骨が細い白 枠と認識され, 誘導色となり枠の効果が成立し，その 白に同化するためと説明できる。しかしながら，残り の脳出血 (症例 7) と脳梗塞 1 (症例 $3 /$ 重症)では, 脳 実質写真濃度の見え方にばらつきが生じて有意差は認 められていない(Table 4).

両者のCT画像の図柄上の特徽的な違いとして, 脳 実質の辺縁部の形状の相違 (例 : 軽症の脳梗塞のよう に脳実質の辺縁部がシャープなもの，脳出血のように 脳実質の辺縁部が出血の影響でやゃボケているもの) 
および脳奏質の図柄，特に黒化度の相違(例：梗塞部 位が小領域に限局している軽症の脳梗塞, 梗塞部位が 㕕範囲に及んでいる重症の脳梗塞)などが挙げられよ j.

このことから，頭部CT画像には白い頭蓋骨が細い 白枠と認識されその影晦を受け，脳実質与真濃度が白 っぽく見える症例と, 細い白枠と認識されず脳実質写 真濃度が白っぽく見えていない症例の 2 種類に大別で きる、したがって，一概に「小脳レベルにおける脳実 質写真濃度は，頭蓋骨の白に同化し枠の効果が常に成 立し，白っぽく見える」とは断言できないことが明ら かになったといえる。これは, 誘導色である白い頭蓋 骨の脸奏質写真濃度の見え方に与えている影響の割合 が症例の違い(図柄の違い：(1)脳聅質の辺緣部の形状 の相違，(2)脳実質の眓柄，特に黒化度の相違など)に よって異なるために, その結果, 被誘導色である弾奏 質写真濃度の見え方が変化して見えるものと説明でき る.

\section{4. 結 語}

(1)頭部CT画像の小脳レベルにおける脳実質写真濃 度の見え方は, 同化, 対比, 枠の効果といった錯 視現象の現れ方に依存し, 症例の違い, 観察者の 違いによって異なることが検証できた. 更に，そ の錯視現象の現れガには観察者の個人差が認めら れた。

(2)頭部CT画像は白い頭蓋骨が誘導色, 脳実質が被 誘導色の輪郭図形の一種と認識され，同化が起こ り脳実質が白っぽく見える症例と白い頭蓋骨が誘 導色と認識されず脳実質が白っぽく見えていない 症例の 2 種類に大別できた。これは, 症例の違い （図柄の違い：(1)脳実質の辺縁部の形状の相違, (2)脳実質の図柄，特に黒化度の相違など)で誘導 色である頭蓋骨の兴実質写真濃度の見え方に及は す影響の度合いが変わるためと思われる。

なお，本論文の一部は，第57回日本放射線技術学会 総会学術大会(平成13年4月，神戸)において発表した。

\section{参考文献}

1）J.P.フリスビー著，村山久美子訳：シーイング 錯視一脳 と心のメカニズム．誠信整房，東京，(1994）.

2) R.N.シェパード著, 鈴木光太郎, 䓅賀康朗訳 : 視覚のトリ ックだまし絵が語るく見る〉しくみ，新曜社，東京， (1999).

3）鈴木光太郎：入門編. 基礎編. 錯覚のワンダーランド. pp.1-42, 関東出版社, 東京, (1997).

4) 太城敬良：見えているのに見えない不思荃！逆さメガネ の心理学. pp.9-62, 河出皆房新皆, 東京, (2000).

5) 大山 正：色と明るさ. 錯視. 視覚心理学への招待一見え の世界へのアプローチ. pp.31-50，117-146，サイエンス 社, 東京, (2000).

6）リチャード.L.グレゴリー著，近藤倫明，中澤幸夫，三浦佳 世訳：錯覚. 脳と視覚一グレゴリーの視覚心理学一. pp.251-313, ブレーン出版株式会社, 東京, (2001).

7）村上克已，原口信次，杉本義弘，他：マスクの見え方の違 いによる画像への影那. 日放技学誌, 47(8), 475-476, (1991).

8) 川上元郎, 児玉 晃, 富家 直, 他 : 色彩の心理 ·生理一 色営(三星宗雄，長谷川敬)。色彩の事典.pp.214-219， 朝合苗店, 東京, (1988).

9) 応用物理学会光学慜話会編 : 色営の生理 (富家 直). 色の 性啠と技術。pp.35-41, 朝合晳店, 東京, (1988).

10) 金子隆芳：ヘリングの心理学的色筧説. 色彩の科学. pp.158-159, 岩波堦店, 東京, (1988).

11 ）金子隆芳：明暗の視営. 色は色を呼び起こす.シュベール から印象派人. 色彩の心理学. pp.17-32, 49-56, 93-108,
岩波覜店，東京，(1990).

12) 小町谷朝生, 小町谷尚子: 色彩. キュクロプスの空一色と 形はどう見えるか一.pp.121-149, 日本出版サービス，東 京, (1996).

13）雨宮政次：色彩の条件. 図形の条件. 形態の様式. 色の錯 筧 同化による視筧効果. pp.7-82, 六耀社, 東京, (2001).

14）辺見秀一：頭部CT画像における「枠の効果」の検証一頭部 CT画像の脳実質写真濃度についての心理学的検討一。 日放 技学誌, 56(7)，946-952，(2000).

15)片山 仁監修: 頭部. X線CTのABC. pp.35-104, 䀢学暂 院, 東京, (2000).

16）佐藤 信: 手法. 官能検查入門. pp.80-91, 日科技連出版 社, 東京, (1999).

17) 佐藤 信：シェッフェの一対比較の原法. シェッフェの一 対比較の芳贺変法. シェッフェの一対比較の浦変法. シェ ッフェの一対比較の中屋変法. 統計的官能検查法. pp.231270, 日科技連出版社, 東京, (1998).

18）大賀泰文，田畑洋二，辻本武士，他：X線写真の主観的評 価法一Thurstoneの一対比較法による尺度化の試み。日放 技学誌, 45(7)，831-839，(1989).

19）田畑洋二, 大賀沶文, 角田充弘, 他：X線写真の主観的評 価法一主観的尺度値の信賴性一。 日放技学誌，49(1)，1217, (1993).

20）中前光弘, 田畑洋二, 大賀泰文, 他: Scheffeの一対比較法 による主観的評価法. 日放技学誌，52(11)，1561-1565， (1996). 


\section{0 困表の説明}

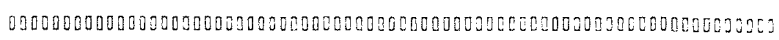

Fig. 1 視覚的主観評価No.1によって得られた評点の平均値と標準偏差.

Dr.He：心臟血管外科医

Dr.Pe：小肾科医

Dr.Su：外科医

Rt.Co：診療放射線技師

(a) : [A] [B], [A][C], [A][D] 3 群間の比較

(b) : $[\mathrm{B}][\mathrm{A}],[\mathrm{B}][\mathrm{C}],[\mathrm{B}][\mathrm{D}] 3$ 群間の比較

Fig. 2 視覚的主観評価No.2によって得られた評点の平均值と標準偏差.

症例 $1:<も$ 膜下出血

症例 $3:$ 脳梗塞 (重症)

症例 $4:$ 脳梗塞(軽症)

症例 $7:$ 脳出血 (重症)

Fig. 3 小脳レベルにおける頭部CT画像の[B][C]間の比較：症例 7, 脳出血(重症)

Fig. 4 小脳レベルにおける頭部CT画像の $[\mathrm{A}][\mathrm{B}]$ 間の比較：症例 4, 脳梗塞No.2(軽症)

Fig. 5 小脳レベルにおける頭部CT画像の [A] [B]間の比較：症例 3, 脳梗塞No.1 (重症)

Table 1 この研究で視覚的主観評価に使用したサンプル画像の疾患名と観察者の人数.

Table 2 視覚的主観評価No.1によって得られた評点の合計とその評価の結果から一標本符号検定法によって得られたp值. かっこ内 の数值は評点の合計である.

Table 3 視覚的主観評価No.2によって得られた評点の合計とその評価の結果から一標本符号検定法によって得られたp值. かっこ内 の数值は評点の合計である.

Table 4 視覚的主観評価No.2によって得られた $[\mathrm{A}][\mathrm{B}]$ 間の観察者個々の評点とその合計および一標本符号検定法によって得られた $\mathrm{p}$ 值.

Table 5 視覚的主観評価No.2によって得られた[B][C]間の観察者個々の評点とその合計および一標本符号検定法によって得られた p值. 